\title{
Fascism's Modernist Revolution: A New Paradigm for the Study of Right-wing Dictatorships
}

\author{
Roger Griffin \\ Oxford Brookes University \\ rdgriffin@brookes.ac.uk
}

\begin{abstract}
This article highlights the progress that has been made within fascist studies from seeing 'fascist culture' as an oxymoron, and assuming that it was driven by a profound animus against modernity and aesthetic modernism, to wide acceptance that it had its own revolutionary dynamic as a search for a Third Way between liberalism and communism, and bid to establish an alternative, rooted modern culture. Building logically on this growing consensus, the next stage is to a) accept that modernism is legitimately extended to apply to radical experimentation in society, economics, politics, and material culture; b) realize that seen from this perspective each fascism was proposing its own variant of modernism in both a socio-political and aesthetic sense, and that c) right-wing regimes influenced by fascism produced their own experiments in developing both a modern political regime and cultural modernism grounded in a unique national history.
\end{abstract}

\section{Keywords}

fascism - modernism - fascist studies - dictatorship

Eventually one of the new points of view triumphs by solving some of the problems posed by the anomalies. It will probably not solve all of the

* This article is a modified version of the English original of 'La revolución modernista del fascismo: un nuevo paradigma para el estudio de las dictaduras de derechos,' in Fascismo y modernism: Política y cultura en la Europa de entreguerras (1919-1945), ed. Francisco Cobo, Miguel Á. Del Arco and Claudio Hernández (Granada: Comares, 2016). 
problems, nor is it likely to be as well developed as the paradigm it promises to displace. Nevertheless, the new paradigm works. It probably does not convert all of the proponents of the now 'classical' paradigm. However, new people in the field tend to be attracted to it, and stubborn devotees of the old paradigm will ultimately die off and become part of history. ${ }^{1}$

\section{Fascism as an Anti-culture}

Only twenty five years ago a conference on the links between modernism and fascism in Italy, Germany, and Spain such as the one held in April 2015 in Granada University on the topic 'Fascism and Modernism'2 would have been inconceivable, except to a small band of scholars whose work was widely regarded as aberrant. ${ }^{3}$ Mussolini's regime was still treated by most Italian historians as sui generis, Nazism was denied fascist credentials by many experts focussed on Germany's Sonderweg to dictatorship, and Franco's regime was assumed to be both fascist and reactionary, rather than as only partially fascist and hosting currents of revolutionary nationalism and modernization. As for 'modernism', it was still firmly established within the Humanities as a term applicable only to radical innovation and experimentation in painting, literature and architecture, possible, if at all, in association with 'progressive' forms of politics, such as radical liberalism and communism. But neither reformist socialism nor communism were seen as political ideologies which were modernist in their own right. Since it was still axiomatically assumed by a majority of historians and political scientists that reaction and anti-modernity lay at the heart of fascism, a project to look for meaningful affinities between modernism and fascism would have been dismissed as futile, and certainly unfundable as a research or conference project. Within this intellectual climate the idea of fascism itself being a modernist political ideology sponsoring its own forms of modernist culture, both social and artistic, was simply alien to the dominant paradigm.

1 William Hillix and Luciano L'Abate, 'The Role of Paradigms in Science and Theory Construction,' in Paradigms in Theory Construction, ed. Luciano Abate (New York: Springer, 2012), 5.

2 For information on the conference 'Fascismo y Modernismo' see https://seminariofascismo. wordpress.com/2015/04/05/1296/, accessed September 14, 2016.

3 I am thinking of such eminent forerunners of the (misleadingly termed) 'culturalist' approach to fascism as George Mosse, Emilio Gentile, Ze'ev Sternhell, and Aristotle Kallis. 
The prevailing logic of the time deterred scholars from looking beneath the surface to discern a powerful revolutionary, futural dynamic behind fascism. After all, how could a political force that represented 'a terroristic form of capitalism,4 'theoretical and practical resistance to transcendence, ${ }^{5}$ or a 'form of ideology without the content' ${ }^{\prime}$ be considered capable of significant cultural production, let alone a future-oriented, modernist one? The Marxist intellectual Andrew Hewitt at least conceded that the relationship of modernism to fascism merited an entire monograph, but within a few pages asks the reader to accept blindly that fascism's 'aestheticization of politics was inscribed from the very outset in the bourgeois construction of the public sphere', and hence formed an integral part of 'capitalism's libidinal project of self-destruction'. Such a dual axiom (a non sequitur based on a long tradition of fusing Marxism with Freudianism in a liaison dangereuse) precluded a priori the possibility modernism and fascism had a natural or elective affinity. ${ }^{7}$

Outside Marxism, the closest fascism came to 'modernism' in received scholarly understanding (and here the term was reduced to meaning little more than 'embracing modernity') was in the argument that it was driven by the paradoxical need to achieve a high degree of technocratic and bureaucratic modernity in order to return to a premodern state of society with anti-modern goals and values which reversed centuries of humanistic (or more recent Marxist) progress. Such a conviction led Henry Turner to coin the paradoxical term 'anti-modern modernism. ${ }^{8}$ Even Jeffrey Herf's concession that the cult of technological advance under Nazism could be seen as 'reactionary modernism' still stemmed from the premise that any evidence of fascist espousal of modern technology or aesthetics conflicted with its atavistic, arch-conservative longings for a pre-modern society and ethos. ${ }^{9}$ He intended the two terms he had conjoined within a forced marriage to point temporally in different directions.

An allusion to what is known as the 'Dimitrov' theory of fascism. See David Beetham, ed., Marxists in Face of Fascism (Manchester: Manchester University Press, 1983).

5 An allusion to Ernst Nolte's famous but utterly cryptic theory of fascism as 'resistance to transcendence' developed in Ernst Nolte, Three Faces of Fascism: Action Française, Italian Fascis, National Socialism (New York: Weidenfeld and Nicolson, 1966).

6 A phrase used in Roger Scruton's extraordinarily vacuous definition of fascism in his Dictionary of Political Thought (Basingstoke: Palgrave Macmillan, 1982).

7 Andrew Hewitt, Fascist Modernism: Aesthetics, Politics, and the Avant-Garde (Stanford, CA: Stanford University Press, 1993), 17.

8 Henry Turner, 'Fascism and Modernization,' in Reappraisals of Fascism, ed. Henry Turner (New York: New Viewpoints, 1975).

9 Jeffrey Herf, Reactionary Modernism: Technology, Culture, and Politics in Weimar and the Third Reich (New York: Cambridge University Press, 1984). 
As for Nazi attitudes to culture, the campaign against 'cultural Bolshevism' which led to the burning of 'decadent' books and contemporary art in stateorganized bonfires of the vanities, had convinced most historians that nothing produced by the Nazis in the realm of art could ever be dissociated from nihilism and genocide. Such a premise informs Peter Adams' famous declaration that Nazi culture cannot be judged by the criteria which apply to artistic production in other regimes, and can 'only be seen through lens of Auschwitz.'10 Inspector Morse in the British TV detective series set in Oxford revealed just how entrenched such assumptions were in the popular imagination when, standing in the famous quadrangle of the Bodleian Library, he deduced 'What we are looking for here is the sort of person that slashes pictures, takes a hammer to Michelangelo's statues, and a flamethrower to books; someone who hates art and ideas so much that he wants to destroy them: a fascist.'11

Compared to Nazism, which had quite reasonably on a common sense level become widely associated with pathological vandalism and the wholesale looting of culture, ${ }^{12}$ Fascism could not be accused of wanton iconoclasm and pillage. Instead, it was simply assumed, often without discussion, to be an anticulture, incapable of genuine creativity. Mussolini's determination to overcome socialism and parliamentary democracy came to be interpreted as a radical rejection of modernity and progress per se, despite the regime's sustained embrace of modern technologies, ${ }^{13}$ modernist architectural forms, ${ }^{14}$ vast schemes of urban renewal, ${ }^{15}$ major elements of a welfare state, ${ }^{16}$ use of mass media, ${ }^{17}$ imposing public works and advanced transport systems, ${ }^{18}$ aviation, ${ }^{19}$ and

$10 \quad$ Peter Adam, Art of the Third Reich (New York: Harry N. Abrams, 1992), 9.

11 The Oxford detective Inspector Morse in the episode of The Twilight of the Gods (first broadcast by the British television ITV in 1993).

12 Lynn Nicholas, The Rape of Europa (New York: Barnes and Noble, 1994).

13 For an example see Jeffrey T. Schnapp, 'Rayon/Marinetti,' in Science and Literature in Italian Culture from Dante to Calvino, ed. Pierpaolo Antonello and Simon Gilson (Oxford: Legenda / MHRA / EHRC, 2004), 225-251.

14 Richard Etlin, Modernism in Italian Architecture, 1890-1940 (London: MIT Press, 1991).

15 F. Caprotti, 'Destructive Creation: Fascist Urban Planning, Architecture and New Towns in the Pontine Marshes,' Journal of Historical Geography 33, no. 3 (2007): 651-679.

16 Maria Quine, Italy's Social Revolution: Charity and Welfare from Liberalism to Fascism (New York: Palgrave Macmillan, 2002).

17 Ruth Ben-Ghiat, Fascist Modernities: Italy 1922-1945 (Berkeley: University of California Press, 2001).

18 Massimo Moraglio, The Shadow of Modernity: Innovation, Technology and Propaganda in Italian Fascist Motorways (forthcoming).

19 Fernando Esposito, Fascism, Aviation and Mythical Modernity (Basingstoke: Palgrave, 2015). 
sport. ${ }^{20}$ It even accommodated a small thriving scientific subculture dedicated to eugenics, a deeply anti-egalitarian, but hardly an anti-modern movement. ${ }^{21}$ There was also the highly conspicuous and stormy relationship between Fascism and Futurism, the epitome of a future-embracing, technophile modernist movement in the arts, yet even this was generally ignored as evidence of a Fascist modernism, or explained away as based on Marinetti's ingenuous misunderstanding of Mussolini deeply anti-futural temperament. ${ }^{22}$

In this hostile academic Zeitgeist Emilio Gentile's brilliant series of essays on different aspects of Fascism's quest to create an alternative to both liberal capitalism and communism which appeared in English as The Struggle for Modernity, ${ }^{23}$ stood out more as a sore thumb than as a beacon in Fascist studies. It had a minimal impact both inside and outside Italy on the academic and public understanding of Mussolini's regime, and simply ignored by a small group of Anglo-American scholars who created a career for themselves as selfordained experts on fascism by recycling ignorant banalities about Fascism's ideological vacuity. Instead, the prevalent attitude of academics to Fascist culture until the 1990s was summed up in Norberto Bobbio's Profilo ideologico del Novecento, where he asserted, somewhat paradoxically:

Despite the lengths to which Fascists went to contrive a 'Fascist culture' and to try to impose it in schools, journals, newspapers and newly created institutions, Fascism ... did not give birth to a culture of its own. Nor did it leave any traces in the history of Italian culture, apart from rhetorical extravagance, literary bombast and hastily improvised doctrines. This is not to say that there was not an intense cultural life during the regime, which was anything but ephemeral; but there was no culture. ${ }^{24}$

20 Pierre Arnaud, Jim Riordan, Sport and International Politics: Impact of Fascism and Communism on Sport (New York: Routledge, 1998).

21 Francesco Cassata, Building a New Man: Eugenics, Racial Sciences and Genetics in Twentieth Century Italy (Florence: CEU Press Studies in the History of Medicine, 2010).

22 Anne Bowler, 'Politics as Art: Italian Futurism and Fascism,' Theory and Society 20, no. 6 (December 1991): 763-794.

23 Emilio Gentile, The Struggle for Modernity: Nationalism, Futurism, and Fascism (Westport, ст: Praeger, 2003).The thesis of Fascism's frenzied preoccupation with modernization and renewal is extensively documented in the analysis of the regime's primary sources relating to the crisis of civilization and its salvation through Mussolini's genius in Pier Giorgio Zunino, L'Ideologia del fascismo (Bologna: Il Mulino, 1985), another ignored classic.

24 Norberto Bobbio, Profilo ideologico del Novecento, Edizione di riferimento (Garzanti, Milano 1993), 184. 
This article is thus addressed to those who still react with perplexity and even scornful indignation when they see books with titles such as Modernism and Fascism, Avant-Garde Fascism, or Fascism and modernism. Politics and culture in Interwar Europe (1919-1945). It will attempt to convince them of three unspoken premises of this title of this article (even if sceptics will be unlikely to read further than the title). First, the concept 'modernism' must logically be extended to embrace not just formal experimentalism in literature, art, and architecture, but a wide range of experimental, innovative phenomena in the spheres of intellectual and spiritual life, social reform, applied science, and radical or revolutionary politics. Their common denominator is that in different ways the projects and movements in question aimed to put an end to what Spengler portrayed as 'the decline of the West', reverse what Max Weber called the 'disenchantment' of modern society, ${ }^{25}$ resolve what Sigmund Freud described as 'the discontents' of civilization, ${ }^{26}$ satisfy modern man's (and woman's) search for a 'soul' explored by Carl Jung, ${ }^{27}$ and remedy what Heidegger interpreted as a loss of 'being at home in the world'. 28

Second, fascism is one such attempt at modernist societal renewal, in this case a 'total' regeneration claiming to restore magic, joy, a new spiritual 'home' and a new phase of civilization inhabited by 'new human beings': once the futural, revolutionary, totalizing dynamic of 'creative destruction' behind fascism's onslaught on liberal and socialist Europe is understood, and, in the case of Nazism, on entire categories of people, it emerges as a form of modernist politics which inspired wide-ranging plans and initiatives to create a new (but historically rooted), 'healthy' and ultra-modern culture.

Third, in their own contrasting ways, both Fascist Italy and Nazi Germany, the only two fascist regimes to be established, attempted in the short time available to them to give birth to a new culture appropriate to the (very different) historical, national and racial revolutions on which they were embarked, a culture which, however incoherent and experimental, can be seen as an attempt to create their modernism. Cultural regeneration was in fascist eyes a heroic enterprise of not just socio-political and economic, but artistic

25 Anthony Carroll, 'Disenchantment, Rationality and the Modernity of Max Weber,' Forum Philosophicum 16, no. 1 (2011): 117-137.

26 Sigmund Freud, Das Unbehagen in der Kultur (Vienna: Internationaler Psychoanalytischer Verlag, 1930), translated as Civilization and its Discontents (London: Hogarth Press and Institute of Psycho-Analysis, 1930).

27 Carl G. Jung, Modern Man in Search of a Soul (New York: Harcourt, Brace \& World, 1933).

28 Julian Young, Heidegger's Later Philosophy (Cambridge University Press, 2002), 33. 
and cultural regeneration, and was presaged by an outpouring of cultural comment, criticism, theorizing and political intervention, often simplistically dismissed as 'rhetoric' and 'bluster'. Certainly fascist cultural politics were propagandistic, but mostly in the original sense of the term bequeathed by the Sacred Congregation de Fide Propaganda: ${ }^{29}$ spreading a genuine faith in imminent national rebirth, ${ }^{30}$ in total palingenesis (regeneration and renewal). Whatever the differing formal characteristics of these cultural experiments to find aesthetic forms appropriate to the fascist revolution, this utopian undertaking can be considered modernist in its socio-political ethos, totalizing ambition, and futural temporality.

Once this point is grasped, it can be seen that other movements pursuing the goals of revolutionary nationalism, and hence members of the extended fascist family, also planned to renew national culture once they had seized state power (e.g. the BUF, the Romanian Legionaries of the Archangel Michael, Arrow Cross, the Portuguese Blue Shirts, the Brazilian Integralist Action). It can also be realized that even regimes which were only outwardly fascist but lacked commitment to a radical social, anthropological and temporal revolution (so remained 'para-fascist'), ${ }^{31}$ still attempted to simulate cultural renewal in their own way, and also hosted idealists committed to a far more radical artistic and architectural regeneration. ${ }^{32}$ In other words, they applied a regenerative, modernizing vision of their role as artists, architects and town-planning, though not a fully or radically palingenetic, and hence fascist, one. Indeed, the aesthetic results of their idealism in the built environment of the 'era of fascism' (1922-1945), while rejecting the radical break with the past of Gropius, Mies van der Rohe, or Le Corbusier, and while spurning the cosmopolitanism of modernist rationalism, can actually be seen as styles and forms which represented the form taken by aesthetic modernism under those regimes, their peculiar idiom of architectural modernism. Semiotically they signified the rejection of communism and liberalism, but still embraced the alternative

29 Peter Guilday, 'The Sacred Congregation de Propaganda Fide (1622-1922),' The Catholic Historical Review 6, no. 4 (January 1921): 478-494.

30 Jakub Drabik, 'Spreading the Faith: The Propaganda of the BUF,' Journal of Contemporary European Studies (forthcoming).

31 António Costa-Pinto and Aristotle Kallis, ed., Rethinking Fascism and Dictatorship in Europe (Basingstoke: Palgrave, 2014).

32 On the existence of a complex interwar New Right made up of movements and regimes all of which sought a solution to the crisis of civilization and which are deeply entwined with and symbiotically related to fascism, see David Roberts' important book Fascist Interactions: Proposals for a New Approach to Fascism and its Era, 1919-1945 (New York: Berghahn, 2016). 
modernity of radical renewal on the basis of regenerated and purified national community, even where it was tempered by compromise with conservatism and a nostalgia for an idealized period of past greatness.

\section{The Limitations of an Aesthetic Concept of Modernism}

On the first point, there has been a gradual shift in the understanding of 'modernism' as a term that should be extended to embrace not just aesthetic, but also socio-political and ideological phenomena. Such a semantic expansion hardly demands a great leap of the historical imagination. A profound affinity between some of the most creative artists and prophets of modernism and the sphere of socio-political innovation is obvious from early twentieth century history. Under Lenin, Russian Constructivists such as Tatlin, Gabo, and Lissitsky, considered it their mission to act as interpreters and proselytizers of the Russian Revolution through poster art, photographs, and architecture, ${ }^{33}$ and left-wing social and political agendas lay at the heart of De Stijl and the Bauhaus. Nor were the political affinities of avant-garde modernists exclusively left-wing. Marinetti and a number of other prominent Futurists saw Fascism as the embodiment of their vision of a new dynamic phase of civilization based on advanced technology, ${ }^{34}$ while numerous artists and architects cultivating undeniably modernist aesthetics felt a deep affinity with (generic) fascism, such as Wyndham Lewis, Ezra Pound, Adalberto Libera, Giuseppe Terragni Gottfried Benn, Ernst Jünger, Emil Nolde, and Leni Riefenstahl (not to mention the modernist credentials ${ }^{35}$ and impact ${ }^{36}$ of Hitler's favourite artist, Richard Wagner). The enthusiasm for a Falangist cultural revolution in Spain of the modernist intellectual and writer Ernesto Giménez Caballero, Salvador Dali's support for Franco, and the adoption of Le Corbusier's vision of urban renewal by French fascists, ${ }^{37}$ are no less significant examples of the porous membranes

33 Richard Stites, Revolutionary Dreams: Utopian Vision and Experimental Life in the Russian Revolution (New York: Oxford University Press, 1989).

Christine Poggi, Inventing Futurism: The Art and Politics of Artificial Optimism (Princeton: Princeton University Press, 2009). Note too the brilliant essay on futurism's relationship to Fascism by Emilio Gentile in The Struggle for Modernity. Juliet Koss, Modernism after Wagner (University of Minnesota Press, 2013).

36 J.A. McGregor, Myth, Music and Modernism: The Wagnerian Dimension in Virginia Woolf's 'Mrs Dalloway' and 'The Waves' and James Joyce's 'Finnegan's Wake' ( PhD diss., Rhodes University, 2009).

37 See Mark Antliff, Avant-Garde Fascism: The Mobilization of Myth, Art and Culture in France, 1909-1939 (Durham, NC: Duke University Press, 2007). 
between modernist aesthetics and politics than Picasso and Miró's support for anarchism $^{38}$ and socialism. ${ }^{39}$

Just how absurd it is to impose a strictly patrolled demarcation between modernist aesthetics and socio-political utopianism left or right in the first part of the twentieth century is clear when the art-historical lens is widened to take in the visionary hopes that lay behind many avant-garde movements. Several of their most important manifestos offered wholesale rejections of the aestheticist ideal of art as a spiritual refuge from a decadent material world. They show how some artists believed they were launching a spiritual revolution (albeit conceived in strikingly different ways) that would solve the moral and existential crisis of modernity and transform material civilization from within. One pioneer of this revaluation of the function of art was Filippo Marinetti. His Futurist Manifesto of 1909 sought to unleash a spring-tide of dynamism in harmony with the technological revolution pulsing through the West which would drown the gerontocracy of the old Italy with its sclerotic cult of gradualism, tradition and antiquity and open the flood gates to the new:

It is from Italy that we launch through the world this violently upsetting incendiary manifesto of ours. With it, today, we establish Futurism, because we want to free this land from its smelly gangrene of professors, archaeologists, tour-guides and antiquarians. For too long has Italy been a dealer in second-hand clothes. We mean to free her from the numberless museums that cover her like so many graveyards. ${ }^{40}$

A year later Wassily Kandinsky published his reflections Concerning the Spiritual in Art which proclaimed that 'anyone, who absorbs the innermost hidden treasures of art, is an enviable partner in building the spiritual pyramid, which is meant to reach into heaven.' As result:

Art must be an integral part of life. It can't be limited to museums. Nonobjective painting has such a great force that no museum or gallery can contain it. Every person who sees these masterpieces will be permanently

38 Patricia Dee Leighten, Re-Ordering the Universe: Picasso and Anarchism, 1897-1914 (Princeton, NJ: Princeton University Press, 1989).

39 Paul Mitchell, 'Joan Miró: An artist "in the service of mankind", World Socialist Web Site, March 27, 2012, accessed September 6, 2016, https://www.wsws.org/en/articles/2012/03/ miro-m27.html.

40 'The Founding Manifesto of Futurism', Italian Futurism, accessed September 6, 2016, http://www.italianfuturism.org/manifestos/foundingmanifesto/. 
affected by them. The people who designed this Museum knew that. Kandinsky, Bauer, Hilla Rebay, and Mr. Guggenheim to me are the symbols of creative progress. It is the artist alone who can save our civilization from chaos, by pointing the way to the world of tomorrow. ${ }^{41}$

Even Dada, often associated with nihilism and infantilism, can be seen as a movement of collective creativity and societal renewal, intent on mobilizing at the height of the mass slaughter, launched by those appalled by the horrors of the First World War and the apparent suicide of the West. It called upon all those touched by art to create a mental tabula rasa of the civilizational values that had led European nations into the cul-de-sac of mutual destruction and create the basis of a new start for humanity. ${ }^{42}$ This is the spirit behind Tzara's exhortation in the Second Dada Manifesto of March 1918, nine months before the end of that terrible war of apocalyptic violence:

Let each man proclaim: there is a great negative work of destruction to be accomplished. We must sweep and clean. Affirm the cleanliness of the individual after the state of madness, aggressive complete madness of a world abandoned to the hands of bandits, who rend one another and destroy the centuries. Without aim or design, without organization: indomitable madness, decomposition. Those who are strong in words or force will survive, for they are quick in defence, the agility of limbs and sentiments flames on their faceted flanks. ${ }^{43}$

In a notably more optimistic vein, now the war had finished and the Second Reich had been abolished, Walter Gropius is no less utopian in the Manifesto of the State Bauhaus published six months after the end of the war. Replete with a striking cover depicting Feininger's woodcut of a cathedral surrounded by Expressionist beams of light, he presented the opening of a school which based architectural training, design and practice on the values of medieval artisans as the first stage in the creation of a new humanistic religion:

41 Wassily Kandinsky, Concerning the Spiritual in Art (New York: Dover Publications, 1997). Available at http://www.gutenberg.org/ebooks/5321, accessed September 6, 2016.

42 P. Prager, 'Play and the Avant-Garde: Aren't we all a little Dada?' American Journal of Play 5 (2014): 239-256.

43 Tristan Tzara, Dada Manifesto, 23 March 1918. Available at http://www.391.org/ manifestos/1918-dada-manifesto-tristan-tzara.html\#.VknYwr_oqq8, accessed September 6, 2006. Significantly, the 'Dada drummer' Richard Huelsenbeck was drawn to communism, while one of Italy's most important ideologues of Fascism and neo-fascism, Julius Evola, had been Italy's leading Dadaist painter. 
So let us therefore create a new guild of craftsmen, free of the divisive class pretensions that endeavoured to raise a prideful barrier between craftsmen and artists! Let us strive for, conceive and create the new building of the future that will unite every discipline, architecture and sculpture and painting, and which will one day rise heavenwards from the million hands of craftsmen as a clear symbol of a new belief to come. ${ }^{44}$

Similarly the ten issues of the journal The Surrealist Revolution (1924-1928) made it abundantly clear that the Surrealists saw their movement as a catalyst to the comprehensive transformation of the West. It is accepted within standard art history that:

The group aimed to revolutionize human experience, including its personal, cultural, social, and political aspects, by freeing people from what they saw as false rationality, and restrictive customs and structures. Breton proclaimed, the true aim of Surrealism is long live the social revolution, and it alone!' To achieve this goal, at various times surrealists aligned with communism and anarchism. ${ }^{45}$

Moreover, if we look further into the sources of such declarations we see that their visionary optimism was influenced by other movements in ideas not normally associated with modernism. Futurists, Expressionists, Dadaists, Sorelians, and radical aesthetes from Van Gogh, Rilke, Stravinsky, D'Annunzio to Virginia Woolf, Bernard Shaw, Wyndham Lewis, and Ernst Jünger believed in the spiritual bankruptcy or insubstantiality of the modern world in its present form.

Many such socially minded modernists struggled to bring about a new age of heroic vitalism based on the power of myth in a spirit informed by the influence of Nietzsche. His promulgation in a mountain torrent of works of such idées-forces as the liberation of the repressed Dionysian in modern human beings, Amor Fati, the Will to Power, Creative Destruction, the Higher Self (Übermensch), and the Eternal Return has been perceptively identified by some critics as profoundly modernist in their own right. ${ }^{46}$ All the most original

\footnotetext{
44 Walter Gropius, Bauhaus Manifesto (April 1919), available at https://www.bauhaus1oo.de/ en/past/works/education/manifest-und-programm-des-staatlichen-bauhauses/index .html, accessed September 6, 2016.

45 R.C. Matteson, 'Surrealism,' Matteson Art weblog, accessed September 6, 2016, http://www .mattesonart.com/surrealism.aspx.

46 Robert Gooding-Williams, Zarathustra's Dionysian Modernism (Stanford, CA: Stanford University Press, 2001).
} 
modernists of the early twentieth century could have taken as an epigraph to their life's work Zarathustra's declaration that 'whoever must be a creator of values in good and evil: verily, he must first be an annihilator and shatter values. 47

Other modernists also drew on sources of inspiration not normally associated with modernism in their fulfillment of Ezra Pound's exhortation to 'make it new'48 Kandinsky was heavily influenced by Theosophy's attempt to respiritualize a world sinking in a morass of materialism; Gropius was inspired by utopian socialism; the Surrealists by Freud's attempt to free modern human beings from a repression of the $i d$ which was a major source of civilizational malaise. By contrast, Gaudi drew on a profound Catholicism reinterpreted through the lens of organicist notions of creation found in late nineteenth century Lebensmystik [life mysticism] which found a spiritual meaning in evolutionary theory. A vitalist thinker such as Bergson and evolutionary philosopher such as Haeckel have considerable claims to be modernist in the way they inject an existence without a metaphysical basis with a new source of transcendence. ${ }^{49}$

The absurdity of not recognizing visionary social and political initiatives as modernist on a par with artistic and architectural innovation is illustrated by the Peckham Experiment in inter-war London. The project originated as a radical attempt to address the pressing problems created by the poor levels of exercise, fitness and health in working class Britain, a growing concern at a time when there was much talk of eugenic solutions to 'degeneracy' on the British left as well as the right. As a pilot, a purpose-built centre was opened in 1935 in a deprived area of South-East London, where for one shilling a week $95^{\circ}$ families gained access to sports facilities, a swimming pool (illuminated by natural light - a remarkable innovation at the time), and health check-ups in a communal environment in stark contrast to the cramped, dark living conditions at the time. The building was designed by Sir William Owens, one of the few British architects at the time convinced that the engineering, function and aesthetics of a building should exist in harmony. The result was a major civic construction which not only reflected the influence of international modernism,

47 Friedrich Nietzsche, Thus Spoke Zarathustra (Oxford: Blackwell, 2005), 100.

48 Ezra Pound, Make it New (New York: Faber, 1934). The deep attraction that Mussolini's Fascism exerted over Pound is unintelligible outside the context of the theory of fascism as a form of political modernism, as Charles Ferrall's Modernist Writing and Reactionary Politics (Cambridge: Cambridge University Press, 2001) makes only too clear. Contrast the essay by a faithful follower of the New Consensus, Matthew Feldman, Ezra Pound's Fascist Propaganda, 1935-1945 (Basingstoke: Palgrave, 2013). 
but which can be seen as an early example of architectural determinism, the belief that new building and innovative design techniques could enhance the effectiveness of social experiments to create a better society. In her monograph devoted to the Peckham Experiment, Re-forming Britain, Elizabeth Darling describes the optimistic ethos created by the collaboration of doctors, architects, health experts and designers of sports facilities in the project as 'social modernism' ${ }^{50}$

Darling's book reveals how reductionist it is to see architectural modernism as an episode in the history of aesthetics without taking into account the wave of social and political utopianism which spread throughout Europe after the First World War, bringing together artists, intellectuals, architects, town planners, industrialists, municipal authorities, educators and political activists in the determination to 'make a new world. ${ }^{51} \mathrm{~A}$ testament to this utopianism, and to the porous membranes between aesthetic, social and political innovation in this period is the catalogue produced to accompany the exhibition Modernism 1939-1945, with the revealing subtitle Designing a New World. ${ }^{52}$ Reading the excellent essays in this catalogue before looking at the vast array of objects with a social function included as examples of modernism, ranging from sanatoria to the Volkswagen, leaves the reader under no illusion that modernism embraces innovation far beyond the narrow spheres of aesthetics and design. The exhibition's curator, Christopher Wilk, himself draws attention to this fact in his introductory essay where he stresses just how many cities generated their own modernist experiments:

All these sites were stages for an espousal of the new and, often an equally vociferous rejection of history and tradition; a utopian desire to create a better world, to reinvent the world from scratch; an almost messianic belief in the power and potential of the machine and industrial technology.... All these principles were frequently combined with social and political beliefs (largely left-leaning) which held that art and design could, and should, transform society. ${ }^{53}$

50 Elizabeth Darling, Re-forming Britain: Narratives of Modernity before Reconstruction (London: Routledge, 2006).

51 Rajesh Heynikx, Tom Avermaete, ed., Making a New World:Architecture and Communities in Interwar Europe (Leuven: University of Leuven Press, 2012).

$5^{2}$ Christopher Wilk, ed., Modernism 1914-1939: Designing a New World (London: V\&A Publications, 2006).

53 Christopher Wilk, 'Introduction: What was Modernism?' in Modernism 1914-1939: Designing a New World, ed. Christopher Wilk (London: V\&A Publications, 2006), 14. 
And yet even this striking expansion of the scope of the term 'modernism', particularly remarkable for the curator of an exhibition held in a museum of the decorative arts and design, did not go far enough. Firstly, as the quotation from Wilk itself suggests, the link of the ideologies of the Bolshevik and socialist left with modernism was fully documented in the exhibition. Yet there was only the most grudging and partial concession to the capacity of the nationalist and fascist right to produce modernist artefacts and little understanding of the possibility that the extreme right could have a radically futural dynamic despite its mythicization of the past. In fact, David Crowley's essay 'Nationalist Modernisms' betrays considerable confusion about the temporality of fascism, giving the reader no clear indication of whether it should be seen as backward- or forward-looking in its relationship to modernity. Significantly, he cites conflicting sources on the topic with no attempt to resolve the contradiction. ${ }^{54}$ Secondly, modernism is still conceived by Wilks in the exhibition artefacts as primarily an aesthetic category, with ancillary phenomena in other spheres. The essays in the catalogue thus collectively fall well short of visualizing the mythic core of modernism as a drive towards innovation and renewal which can manifest itself in any sphere of intellectual, artistic, social, economic, scientific, political, or cultural production, in the extreme left, extreme right or reformist centre. Nor does it focus on the paradox that modernism can express itself both as an agent of societal change, but equally well without the goal of transforming the world beyond the artist's or intellectual's private experiential horizon.

\section{Modernism as the Quest for Radical Cultural and Social Renewal}

It was such lacunae in the pronouncements on modernism of even the more enlightened cultural commentators as late as the 200os, combined with the persistent reluctance in some academic quarters to recognize the futural, modernizing, and cultural dimension of generic fascism, that prompted me to embark on the intensive programme of research that finally led to my Modernism and Fascism. ${ }^{55}$ The core thesis of the first half of the book is that

54 David Crowley, 'Nationalist Modernisms,' in Modernism 1914-1939: Designing a New World, ed. Christopher Wilk (London: V\&A Publications, 2006).

55 Roger Griffin, Modernism and Fascism: The sense of a Beginning under Mussolini and Hitler (London: Palgrave, 2007). The title alludes to a famous book by the English literary critic Frank Kermode, called The Sense of an Ending (New York: Oxford University Press, 1967) 
modernism in literature, painting, sculpture, music, architecture and design is only one manifestation of attempts in every sphere of creativity and activism in society to find new sources of expression, meaning, gnosis, transcendence, reality, agency in the modern world. The mainspring of all modernism is that the nexus of forces known as modernity is constantly undermining traditional forms of existential security and understanding of the human place in the cosmos. Using Peter Berger's term 'nomos' for the totalizing set of normative beliefs and practices that constitute meaningful lives in traditional societies, modernity can be characterized as 'nomocidal', as eroding or destroying the 'sacred canopy' that premodern religions erected over secular existence to protect it from the infinite void. The nomocidal, desacralizing impact of modernization is expressed in any number of different concepts, such as Barrès' idea of 'uprootedness', Weber's 'disenchantment', Durkheim's 'anomie', Nietzsche's 'Death of God', Hölderlin's 'Flight of the Gods', Heidegger's erosion of 'being', Jung's loss of 'soul', Sartre's revelation of 'the superfluity' of each human life, Cioran's obsession with 'decomposition', Beckett's 'endgame', Becker's 'death of meaning', Giddens' 'disembedding' of human beings from time and space.

If this premise about the entropy of absolute meaning under the impact of a globalizing modernity is accepted, then modernism can be seen at work in any form of palingenetic rebellion against the haemorrhage of transcendent significance from the world, any attempt to infuse modern existence with more beauty, health, communality, spirituality, transcendence, hope once it is conceived by the artist or protagonist of change as an antidote to the 'decadence' of the secularizing, atomized West which is creating a spiritual wasteland. As T.S. Eliot reminded us, even in the most densely packed metropolis 'The desert is squeezed in the tube-train next to you'.56 Modernism, then, can be conceptualized as a rebellion against modernity, the palingenetic attempt to create a new nomos. It is not anti-modern, but an assault on existing modernity, and postulates a new vision of life, an alternative modernity. ${ }^{57}$ It can take the form of a private, highly personal, but still artistically communicable revelation of deeper, unexplored realms of meaning and revelatory facets of existence, with no bid to change society or 'the world' as such, which I term 'epiphanic modernism'. Alternatively, it can be experienced as a mission to transform one segment of society, a nation, or even create a whole new civilization, an ambition

that characterizes fascism as fostering an apocalyptic sensibility without a corresponding belief in a new order or brave new world.

56 T.S. Eliot, Choruses from the Rock (1934).

57 A realization central to Ben-Ghiat, Fascist Modernities. 
typically expressed in manifestos or programmes, and which can thus be called 'programmatic modernism'.

The distinction can be illustrated by the case of Van Gogh, widely considered one of the supreme modernists in the history of painting. ${ }^{58}$ His artistic life was dedicated to crafting compositions in form and colour to express his intense emotional inner life and his presentiments of a higher spiritual world, but he had little interest in selling his canvases, let alone launching a movement of 'Van Goghism'. Indeed, one of his letters to his brother Theo reveals he saw his art as an act of gratitude to the earth on which he had lived. ${ }^{59}$ His modernism was thus thoroughly 'epiphanic'. Yet he was fascinated by Tolstoy's My Religion precisely because it suggested to him the possibility of a movement that would transform the spirituality of a world he saw plunging into chaos and war, and thus provide a new nomos for human life:

Tolstoy implies that whatever happens in a violent revolution, there will also be an inner and hidden revolution in the people, out of which a new religion will be born, or rather, something completely new which will be nameless, but which will have the same effect of consoling, of making life possible, as the Christian religion used to. ${ }^{60}$

Such a velvet revolution, had it materialized and mobilized a significant number of Europeans to avert the horrors of the twentieth century, would have been a spectacular example of a benign form of programmatic modernism attempting to re-enchant, 'renomize' the world, to restore its sacred canopy, to make life existentially possible once more. But the activist modernism of the sort exemplified in Tolstoy may have more modest ambitions, focusing simply on the reform of particular aspects psychological, physical, social or spiritual

58 Albert Boime, Revelations of Modernism: Responses to Cultural Crises in Fin-de-Siècle Painting (Columbia, London: University of Missouri Press, 2008), 1-10, chapter 1, 'Van Gogh's Starry, Starry Night. After the Apocalypse a Heavenly Utopia.'

'The world concerns me only in so far as I owe it certain debt and duty, so to speak, because I have walked this earth for 30 years, and out of gratitude would like to leave some memento in the form of drawings and paintings - not made to please this school or that, but to express a genuine human feeling.' Letter from Vincent van Gogh to Theo van Gogh, The Hague, c. 4-8 August 1883, Van Gogh's letters: unabridged and annotated, accessed September 6, 2016, http://www.webexhibits.org/vangogh/letter/12/30g.htm.

6o Letter from Vincent van Gogh to Theo van Gogh, Arles, 24 September 1888, Van Gogh's letters: unabridged and annotated, accessed September 6, 2016, http://www.webexhibits .org/vangogh/letter/18/542.htm. 
reality as a defence against the howling 'storm of progress' ${ }^{61}$ Modernism and Fascism argues that not just the Peckham Experiment was an example of social modernism, but also the movements inspired by the ideas of Tolstoy, Freud, Nietzsche, Jung, and Haeckel, ${ }^{62}$ and the popularity of Blavatsky's theosophy, and Rudolf Steiner's anthroposophy. In this context Wassily Kandinsky was trebly modernist: aesthetically modernist as an original abstract painter, programmatically modernist, as a visionary who wanted to disseminate theosophical ideas through his innovative use of colour and form, and the composer of one of the major twentieth century manifestos promulgating the need for the spiritual transformation of modernity through art.

Other phenomena of the early twentieth century never generally associated with the term modernism can now be seen as manifestations of the impulse to reverse the slide of the Western world into the black hole of absurdity and the 'death of culture':63 the Catholic revival (that helped shape Gaudi's art), the revival of occultism, ${ }^{64}$ and the increasingly chauvinistic nationalism that perverted democratic nationalism from an Enlightenment project into a pseudoreligion glorifying war, sacrifice, and xenophobia ${ }^{65}$ Equally modernist was the growing biological racism that mixed pseudo-scientific ideas of 'purity' of bloodlines with imperialist and nationalist assumptions about a hierarchy of humanity to offer a new sense of collective identity, belonging, home, and destiny to those convinced they were members of a superior branch of homo sapiens. ${ }^{66}$ No less programmatically modernist was the new scientistic creeds of eugenics ${ }^{67}$ (described by Galton as 'the religion of the future') and social hygiene as the cure to degeneration both biological and spiritual. ${ }^{68}$ All envisaged the inauguration of a new temporality by redirecting the flux of history itself towards a different future, the hallmark of the modernist concept of history

61 An allusion to the famous image of modernity used by Walter Benjamin in his 'Theses on the Philosophy of History', no. IX, in Illuminations (London: Fontana, 1992).

62 Richard Noll, The Jung Cult (New York: Simon \& Schuster, 1994).

63 Mario Vargas Llosa, Notes on the Death of Culture: Essays on Spectacle and Society (London: Macmillan, 2015).

64 John Bramble, Modernism and the Occult (Basingstoke: Palgrave, 2015).

65 Michael Burleigh, Earthly Powers: Religion and Politics in Europe from the French Revolution to the Great War (New York: Harper Collins, 2005); Michael Burleigh, Sacred Causes: Religion and Politics from the European Dictators to Al Qaeda (New York: Harper Collins, 2006).

66 Léon Poliakov, The Aryan Myth: A History of Racist and Nationalist Ideas in Europe (London: Heinemann, 1974).

67 Francis Galton, 'Eugenics: its definition, scope, and aims,' The American Journal of Sociology 10, no. 1 (1904).

68 Marius Turda, Modernism and Eugenics (Basingstoke: Palgrave, 2010). 
according to such innovative cultural historians as Reinhard Koselleck, ${ }^{69}$ Peter Osborne, ${ }^{70}$ and David Ohana. ${ }^{71}$

\section{Fascism as a form of Political Modernism}

But it was in the sphere of revolutionary politics that the most powerful explosions of revolutionary, palingenetic, and thus modernist energies occurred. The twentieth century rebellions against the status quo in the name of a totally new order were no longer directed against the tyranny of divine monarchs as in the eighteenth century, but against modernity itself. Late nineteenth century anarchism and early twentieth century Bolshevism both sought radical solutions not just to capitalist exploitation and class division, but also to social and existential alienation. Both were fuelled by the vision of a final stage of creative, harmonious, communal living that would abolish the horrors of 'history'. Both offered their followers a totalizing nomos, the prospect that if they joined the struggle they would help humanity overcome the bewildering ambivalence of modernity ${ }^{72}$ and resolve the crisis of nihilism. Both provided their fanatics with the powerful sense of living at the cutting edge of history, engaged personally in a vast historical process of renewal.

But whereas the path which would lead to the anarchist utopia remained shrouded in the mists of utopia, Soviet Russia sought to re-engineer every aspect of Russian life, not just culturally, politically, economically, but anthropologically, ${ }^{73}$ at whatever human cost. It was a revolutionary bid to control the development of society and history itself which leads Bauman to describe it as a 'gardening state', ${ }^{74}$ convinced that society had to be totally revisioned, replanned, reshaped, replanted, with all values revalue with a Nietzschean radicalism. This, in the case of Bolshevism, meant being prepared to throw human weeds on bonfires for the sake of the new socialist order. Stites documents the outpouring of aesthetic and social modernism triggered by

69 Reinhard Koselleck, The Practice of Conceptual History: Timing History, Spacing Concepts (Stanford, CA: Stanford University Press, 2002).

70 Peter Osborne, The Politics of Time: Modernity and the Avant-garde (London: Verso, 1995).

71 David Ohana, The Futurist Syndrome (Eastborne: Sussex Academic, 2010).

72 Zygmunt Bauman, Modernity and Ambivalence (Cambridge: Polity, 1991).

73 Michael Geyer, Sheila Fitzpatrick, ed., Beyond Totalitarianism: Nazism and Stalinism Compared (Cambridge: Cambridge University Press, 2008).

74 Tilman Schiel, 'Modernity, Ambivalence and the Gardening State,' Thesis Eleven 83, no. 1 (November 2005), 78-89. 
Lenin's seizure of power, ${ }^{75}$ but by realizing that Bolshevism itself was a modernist political movement, the affinity so many artists and innovators felt with the new regime becomes explicable. So does the fact that Nietzsche had such a profound impact on the ethos of Stalinism. ${ }^{76}$

At this point in the process of radically revisioning modernism, Modris Eksteins' Rites of Spring has the effect of a flare exploding against a dark night sky to illuminate enemy lines. In a book drenched with empiricism but sparkling with fresh insights he convincingly he makes a direct link between the first performance of Stravinsky's Le Sacre du printemps, a spectacle enacting, through modernist music, staging, and ballet, a ritual sacrifice to awaken the primordial forces of nature, with the orgy of fanatical blood-sacrifice to the twin Molochs of nationalism and imperialism in the First World War, the feverish cult of aviator heroes unleashed by the first long-distance solo flights, and Nazism's bloody experiment in creative destruction. The sympathetic reader emerges from the book able perhaps for the first time to survey the early twentieth century from high up on a new promontory, gazing down on a historical panorama in which fascism's modernism seems self evident, a product of what he calls post-ww1 'craving for newness' which was 'rooted in what was regarded by radicals as the bankruptcy of history and by moderates as at least the derailment of history' ${ }^{77}$

Peter Osborne's Politics of Time provides a philosophical basis for the interwar pandemic of neophilia and palingenetic longings that permeated every sphere of private and public life alongside feels of deep-seated ontic angst. He relates modernism to the new experience of time that arose under the impact of modernity and the concomitant decay of metaphysical certainties regarding a supranatural realm of heavenly reality and a divinely ordained purpose for human history. With the growing evanescence of suprahistorical time, history itself became the arena for transcendence. Aesthetic and philosophical modernism was a manifestation of a constant tension between (disenchanted) actuality and (utopian) expectations of radical transformation, the watershed experienced subliminally by so many between the 'temporality of the old' and the possibility of a radically different and unprecedented future temporality born of the self-reflexive temporalization of history. In this context modernism can be conceived as 'the affirmative cultural self-consciousness of the

\footnotetext{
75 Stites, Revolutionary Dreams.

76 Bernice Rosenthal, New Myth, New World: From Nietzsche to Stalin (University Park: Pennsylvania State University Press, 2002).

77 Modris Eksteins, Rites of Spring: The Great War and the Birth of the Modern Age (Boston: Houghton Mifflin, 1989), 257.
} 
temporality of the new, ${ }^{\prime} 8$ expressing itself not just in art, but in philosophy and, above all, in political movements that seek to realize alternative temporalities to resolve the perceived, existentially real crisis of history experienced as acute, even unbearable anomie. Once the modern radical right is seen as attempting to realize an alternative to liberalism, communism and conservatism it becomes clear that the reactionary modernism of the Nazis was not, as Jeffrey Herf erroneously assumes, a hybrid of two different temporalities (modernism + reaction). Instead, Osborne points out, the term 'draws attention to the modernist temporality of reaction per se once the destruction of traditional forms of social authority has gone beyond a certain point. ${ }^{79}$ The battle between socialism and fascism is thus not between 'revolution' and 'reaction' but between 'the revolutionary temporality intrinsic to socialist projects for the overthrow of capitalism'; and the 'counter-revolutionary temporality of a variety of reactionary modernisms', both fundamentally futural in their orientation. ${ }^{80}$

This line of argument leads ineluctably to a conclusion that would have shocked several generations of historians of fascism and historians of modern art: 'From the standpoint of the temporal structure of its project, fascism is a particularly radical form of conservative revolution.' As such it is 'neither a relic nor an archaism', but a 'form of political modernism. ${ }^{81}$ Osborne reaches this conclusion as a philosopher of the politics of time. It is thus significant that a convergent verdict is arrived independently by a historian of the Third Reich, Peter Fritzsche. He expresses succinctly the expansion of the semantic remit of the term 'modernism' that follows when it is approached as a historical, and temporal rather than an aesthetic one. Its hallmark is that 'it breaks with the past, manufactures its own historical traditions, and imagines alternative futures'. As a result, 'though it has usually been conceived in literary or artistic terms', modernism has 'remarkable social and political implications'. ${ }^{82}$ Pursuing the notion that modernism should be used to refer to radical political experiments that break with the past, Fritzsche comes to a remarkable conclusion with regard to the Nazis:

Again and again, modernists staged history as a boundary situation. The most spectacular displays of modernism are not to be found in a museum

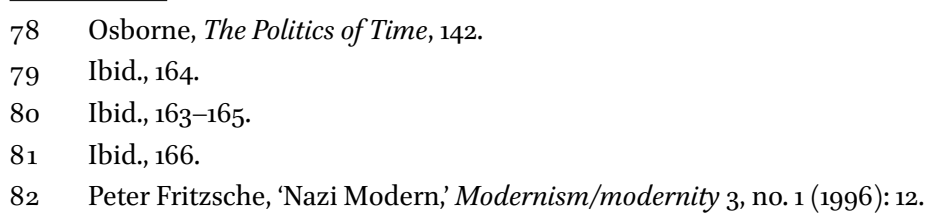


of expressionist art or a collection of prose poetry, but in the avant-garde political collaborations that sought to come to terms with a brand-new world regarded as unstable and dangerous. With every step, the political adventurer as much as the modernist poet or painter revealed ground that was tremulous, breaking apart, unclear. Liberal certainties that proposed to reveal the coherence of the world appeared completely inadequate. But whereas the latter made manifest the disenchantment that had been revealed, the former proposed more fearsome designs to overcome it. 83

My Modernism and Fascism explores at considerable length the temporality of modernity which breeds anomie (experienced as decadence, decline and loss of roots) and the countervailing attempts to overcome the 'nomic' crisis which can all be seen as forms of modernism. I introduce the distinction between artistic attempts to capture the experience of modernity or postulate new visions which will reverse its debilitating spiritual effects (epiphanic modernism) and attempts to change the course of history itself (programmatic modernism). It then introduces the idea of socio-political modernism and interprets the modernist forces which gave rise to fascism and which the two fascist regimes attempted to harness in order to produce a new culture, a new order, a new man, and a new civilization. The two fascist regimes can then be seen as modernist states seeking regeneration and palingenesis in every aspect of cultural, social, economic, military, imperialist, and in the case of the Third Reich, racial policies. ${ }^{84}$

This radical revisioning of fascism as a futural, modernist 'gardening state' 85 has particularly profound implications for how the cultural policies, and art and architecture of both fascist regimes are approached. Instead of seeing them through the lens offered by Walter Benjamin's theory of 'aestheticized politics', or Peter Adams' 'lens of Auschwitz', they too can be seen as modernist in ethos, even when they are not modernist in the aesthetic sense created by the History of Art and Architecture. The curiously lifeless, expressionless

83 Ibid.

84 It is the premise that fascism was driven by a palingenetic vision of national and racial renewal that is the hallmark of the convergence of scholarly approaches to fascism on the question of its revolutionary dynamic known by the shorthand term 'New Consensus' in Fascist Studies. See Aristotle Kallis, The Fascism Reader (London: Routledge Readers in History, 2003) and Constantin Iordachi, Comparative Fascism Studies: New Perspectives (London: Routledge, 2009) for critical accounts of this phrase, and Roberts, Fascist Interactions for a call for academics to move beyond its limitations.

85 Bauman, Modernity and Ambivalence, 15. 
classicist nudes of Nazi 'German art' are obviously not formally modernist in the way the canvases Van Gogh or Kandinsky, and the stripped neoclassicism ${ }^{86}$ of the Nazis' Tempelhof airport ${ }^{87}$ is hardly formally innovative in the same sense as a contemporary building by the Vesnin brothers projected for Stalin's Russia. ${ }^{88}$ But in both cases the art is being conceived in a modernist spirit as embodying the construction of a new world by a new state in which cultural production is no longer dominated by the arbitrary forces of laissez-faire capitalism or the whims of individual 'genius'.

In other words, the modernist architecture that flourished under Mussolini is to be seen not just in the projects of architects such as Giuseppe Terragni and Adalberto Libera who were visibly inspired by international rationalism and utopian currents of architectural experimentation, but also in the far less futuristic civic buildings, urban schemes and exhibition spaces conceived by Giuseppe Pagano and Marcello Piacentini which strove to find a harmonious synthesis between the classicism of Romanità and the aesthetic and construction techniques of international modernism which represented another variant of Fascist modernism. It is consistent with this that Emily Braun's groundbreaking study of Mario Sironi reveals a gifted artist tenaciously experimenting with total dedication to the mission to find an aesthetic that epitomized his understanding of the Fascists' national revolution based on a 'rooted modernism', an embrace of the modern age tempered by a heightened awareness of Italy's Roman and neo-classical past. Again, the result was often a hybrid of traditionalism and modernism aesthetically, but in Sironi's understanding of the mission of creativity under Fascism it was entirely modernist: it was Fascist modernism, as opposed to Bolshevik modernism, or the modernism of Western individualism. To someone familiar with the vital contributions made by Walter Adamson on the relationship between the avant-garde culture of early twentieth century Milan and early Fascism ${ }^{89}$ or Mark Antliff's ground-breaking work

86 It is finally starting to be recognized that the stripped classicism that was so widely used in the 1930 is actually to be seen not as a rejection of aesthetic modernism in architecture but one of its many dialects: see Brittany Bryant, 'Reassessing Stripped Classicism within the Narrative of International Modernism in the 1920s-1930s' (PhD diss., Savannah College of Art and Design, 2011).

87 '“No" for Tempelhof,' Eikongraphia, June 5, 2008, accessed September 6, 2016, http://www. eikongraphia.com/?p=2432.

88 Ivan Leonidov, 'Top 10 unbuilt towers: Narkomtiazhprom,' BDonline, October 11, 2011, accessed September 6, 2016, http://www.bdonline.co.uk/top-10-unbuilt-towers-narko mtiazhprom-by-ivan-leonidov/5026252.article.

89 Walter Adamson, Avant-garde Florence: From Modernism to Fascism (Cambridge, MA: Harvard University Press, 1993). 
on the modernism so central to both Fascism ${ }^{90}$ and French fascists, ${ }^{91}$ these assertions will be practically self-evident. Now that it is commonplace to assume that fascism is defined by its palingenetic dynamic of national and racial regeneration of international comparative fascist studies and a steady trickle of original monographs produces irrefutable empirical evidence of Fascism's attempted cultural revolution, the scathing dismissal of Emilio Gentile as a 'culturalist' by the self-styled expert on Fascism Richard Bosworth ${ }^{92}$ smack increasingly of a bygone era in fascist studies, a dead paradigm.

In contrast Aristotle Kallis' The Third Rome demonstrates what can be done when rigorous empiricism is combined with methodological and conceptual sophistication, as well as a genuine interest in Fascism as a collective project of total cultural renewal and not just the emanation from the fevered brain of a narcissistic leader. It allows the past to be excavated, and not just reconstructed as a glorified newsreel of major events collated with the shallowest understanding of psychology, ideology, political culture, and Italy itself. The result of Kallis' research is a triumphal vindication of the thesis that Fascism took very serious the mission of turning Rome into a living symbol of a new civilization which allowed its own mythicized past to shape its creative vision and provide the aesthetic inspiration and role model for its own totalitarian modernism. His book depicts the intense disputes among extremely gifted architects who welcomed the Fascist regime as one which not only took grandiose projects of urban renewal and major civic building seriously, but offered the prospect for architects to establish the style and ethos of the new state. Take Giuseppe Pagano, for example, who passionately:

defended his position as an authoritative but independent - and often unpredictable - voice in the architectural debates of the Fascist period. He never ceased to argue in favour of an honest, authentic modernist architecture in Italy that was at the same time cosmopolitan, rooted in timeless design values, deeply rooted in an ethical conception of life, fiercely anti-monumental and anti-academic, and appreciably Italian. ${ }^{93}$

9o Matthew Affron and Mark Antliff, ed., Fascist Visions (Princeton, NJ: Princeton University Press, 1997).

91 Antliff, Avant-garde Fascism.

92 Richard Bosworth The Italian Dictatorship (London: Arnold, 1998), 25. His vacuous introduction to The Oxford Handbook of Fascism (2010), which he was prepared to edit for Oxford University Press despite not believing in the existence of a definable generic fascism or in any deep-seated affinity between Fascism and Nazism, compounds his disservice to fascist studies.

93 Aristotle Kallis, The Third Rome, 1922-1943: The Making of the Fascist Capital (Houndmills, Basingstoke, Hampshire: Palgrave Macmillan, 2014), 70. 
In terms of the present argument, this passage demonstrates that he was thus intent on establishing his particular vision of Fascist modernism, a rooted modernism that epitomized the Fascist bid to carry out the total renewal of Italy in the spirit of a heroic past. The ideological, visionary seriousness of the disputes between Fascist architects, also documented in detail by Richard Etlin in his magisterial Modernism in Italian Architecture 1890-1940, makes nonsense of the historical accounts of Fascism or the Duce cult as ideologically hollow phenomena devoid of serious visionary aspirations, accounts which unfortunately still manage to garner critical acclaim from those who prefer their history 'lite' and lack the historiographical curiosity and conceptual rigour to appreciate the more demanding fruits of scholarship which combines empiricism with historical imagination. ${ }^{94}$

Our argument also has profound implications for the way Fascism and Nazism should be treated as cultural phenomena by scholars who have seemingly not progressed beyond Bobbio's puerile reduction of Fascist culture to 'rhetorical extravagance, literary bombast and hastily improvised doctrines', or still uncritically parrot Walter Benjamin's specious judgments on the fate of art under fascist dictatorship. ${ }^{95}$ It suggests that the Fascist and Nazi states succeeded far more than has been realized in carrying out the politicization of art with more genuine revolutionary intent and more radical aesthetic consequences than Bolshevism and Maoism could ever aspire to do. If anything it is Bolshevism that ended up in practice aestheticizing the politics of repression, the systemic exploitation of the masses, and revolutionary self-deception. The Romanized rationalism of Fascism and the 'Aryanized' architecture of Nazism were more faithful statement of Nazi biopolitics than the projects born of constructivist, social realist theory and Stalin's megalomania were reflections of the State Socialist ideals under Bolshevism.

And what of the several inter-war regimes which lacked genuine fascism's profound palingenetic aspirations, but which deliberately modelled the institutions, political religions and style of their authoritarianism on Fascism or Nazism so as to associate themselves with their youth, dynamism, modernity, and popular consensus? The outstanding examples of these were the political experiments carried out under Salazar, Franco, and Horthy which were neither fascist nor traditionally conservative. Here too a paradigm shift is well underway, especially among younger European scholars, that allows the

94 Richard Etlin, Modernism in Italian Architecture, 1890-1940 (London: MIT Press, 1991).

95 The concept is introduced in Walter Benjamin's essay The Work of Art in the Age of Mechanical Reproduction (Schocken/Random House, 1936) at the height of Stalinism. 
cultural and architectural creativity of such 'parafascist' regimes ${ }^{96}$ to be seen not as the bogus art of reactionary repression, but as serious experiments to find a modernist style of authority and culture appropriate to the idiosyncratic blend of traditionalism and modernization being pioneered by the regime. ${ }^{97}$

It is personally gratifying to have lived long enough to see theories of fascism's palingenetic dynamics, which only two decades ago were still widely ignored or treated as heretical, to be assumed as self-evident. Perhaps one day fascism's modernism will also be taken for granted. In the meantime it is a sign of the growing vitality and vigour of comparative right-wing studies that Franco's regime is increasingly recognized as driven by anti-fascist, ultra-conservative instincts which were still futural enough to allow for genuine creative gestures towards an alternative Spanish modernity. ${ }^{98}$ If such a scholarly initiative were to be duplicated in every country in Europe and Latin America which experienced authoritarianism of the right in the period 1920-1975 it could lead to an international palingenesis in the historical understanding of the fascist era as one embracing a wide spectrum of fascist and other radical right phenomena. ${ }^{99}$ Would this not be a splendid tribute to the survival of the Enlightenment humanism which both fascism and parafascism were so determined to destroy in their life-time?

96 Costa-Pinto and Kallis, Rethinking Fascism and Dictatorship.

97 See, for example, Max Guerra et al., Urbanism and Dictatorship: A European Challenge (Berlin: De Gruyter, 2015), and the special issue 'Latin Architecture in the Age of Fascism,' Roger Griffin, ed., to be published in Fascism in 2017. For the need to integrate fascism's history more closely into that of the new inter-war right more generally see Roberts, Fascist Interactions.

98 See in particular ed. Francisco Cobo et al., Fascismo y modernismo, (Granada: Comares, 2016).

99 Such a development in fascist studies is argued for in Roberts' Fascist Interactions. 